www.jmscr.igmpublication.org

Impact Factor (SJIF): 6.379

Index Copernicus Value: 71.58

ISSN (e)-2347-176x ISSN (p) 2455-0450

crossref DOI: https://dx.doi.org/10.18535/jmscr/v6i6.143

Journal Of Medical Science And Clinical Research

IGM Publication

An Official Publication of IGM Publication

\title{
Comparative evaluation of antigen ELISA technique and PCR for detection of Rotavirus in stool samples of pediatric patients with diarrhea
}

\author{
Authors \\ Neeraj Kumar, Bharti Malhotra, SK Mehra, Janardhan Reddy, Pratibha Sharma \\ and Renuka Chauhan
}

\begin{abstract}
Background: Acute diarrheal disease is a common infection of young children and adults which is characterized by rapid dehydration of body fluid. Iidentification of the causative agent and timely treatment can be life saving of children. The objective of this study was to detect Rotavirus (RV) in stool samples and to compare ELISA and RT-PCR techniques.

Methods: Hospitalised children less than 5 years admitted for acute diarrhea were examined and clinical profile of diarrhea in the children. Detection of Rotaviral antigen in stool samples was done by a commercial Enzyme Immuno Solvent Assay Premier Rotaclone kit (Meridian Bioscience, Inc.) and the samples were processed for extraction of nucleic acid using an automated extraction system and RT-PCR was performed.

Results: A total of 135 stool samples were tested by ELISA and RT-PCR. A total of 20/135 (14.81\%) samples were found to be positive for RV infection by ELISA. Positivity of RV by RT-PCR was 33/135 (24.44\%). The positivity by ELISA was significantly lower than by RT-PCR. The sensitivity and specificity of $P C R$ for detection of $R V$ was $100 \%$.

Conclusion: RT-PCR is a better and sensitive technique as compared to ELISA for detection of Rotavirus.
\end{abstract}

\section{Introduction}

Acute diarrheal disease is a common infection of young children and adults which is characterized by rapid dehydration of body and one of the most important worldwide causes of morbidity and mortality, accounting for an estimated 1.3 million deaths in children under five aged ${ }^{(1,2)}$. Clinically, rotavirus gastroenteritis is characterized by profuse diarrhea, mild fever, and vomiting, leading to mild to severe dehydration. Rotavirus is the major cause of acute gastroenteritis and severe dehydrating diarrhea in young children $^{(3)}$. Rotavirus is estimated to cause about $40 \%$ of all hospital admissions due to diarrhea among children under five years of age worldwide ${ }^{(4)}$

In India rotavirus is responsible for $40 \%$ of children diarrhea hospitalization and approximately $527,000 \quad(475,000 \quad-580,000)$ deaths annually (5) or 29 to $45 \%$ of all death due to diarrhea among children $\leq 5$ year of age globally $^{(6,7)}$. Several techniques have been developed to detect rotavirus in stool samples, including electron microscopy, polyacrylamide gel electrophoresis (PAGE) of viral nucleic acid, various immuno assays, and PCR-based molecular methods $^{(1)}$. Several rapid methods, such as the 
immunochromatographic test and the latex agglutination test (LA), have been evaluated and compared to other methods, such as enzymelinked immunosorbent assays (ELISA) and quantitative reverse transcription - polymerase chain reaction (RT-PCR) and they have shown a wide range of sensitivity and specificity ${ }^{(8)}$. The performance of those rapid tests indicated that they could be used for screening but not for confirmation of the disease. Therefore, a highly specific and sensitive test is a pressing need for use in confirming rotavirus infections ${ }^{(9)}$. Laboratory diagnosis of rotavirus infection is usually performed by antigen detection, using enzyme immunoassay or LA techniques, which have a sensitivity and specificity above $90 \%$. Molecular techniques such as PAGE and RT-PCR are used to determine the RNA migration patterns and virus genotyping, respectively ${ }^{(10-13)}$.

ELISA and RT-PCR are being used in research settings. In recent years, ELISA has become the method of choice for screening. The sensitivity of routine diagnostics is high since the amount of virus excreted by a child with rotavirus diarrhea $\left(\sim 10^{10}\right.$ viruses/g of stool) far exceeds the level of detection $\left(\sim 10^{7} \text { viruses/g of stool }\right)^{(14)}$. Early studies on strain surveillance identified rotavirus serotypes using neutralization assays. Monoclonal antibodies to specific serotypes were used. New methods have greatly improved data on circulating rotavirus strains and include multiplex RT-PCR based genotyping, hybridization assays and nucleotide sequencing ${ }^{(15)}$.

\section{Material and Methods}

A total of 135 stool samples of children of age $\leq 5$ years admitted in wards of the Department of General Medicine at J K Lone Hospital, Jaipur were enrolled in the study. All children were suffering with diarrhea, vomiting, headache, signs and symptoms fever, chills and abdominal pain. Approval by the institutional Ethics committee has been granted for the present study.

\section{Sample collection and transportation}

Samples were collected from suspected or clinically diagnosed cases of gastrointestinal tract infections in to a sterile transport container. The stool samples were properly labeled \& transported in cold chain $\left(4-8^{\circ} \mathrm{C}\right)$ at the earliest to the laboratory and stored the samples $-80^{\circ} \mathrm{C}$ until further investigations.

\section{Detection of rotavirus by ELISA}

ELISA for RV was performed using Commercial kit, Premier Rotaclone EIA kit (Meridian Bioscience, Inc.) as per manufacturer's instructions. This kit is used to detect the presence of viral antigen (VP6) for RV was tested by in a solid phase sandwich ELISA. The antigen is sandwiched between anti RV monoclonal antibody and enzyme linked antibodies.

\section{Nucleic Acid Extraction}

Viral nucleic acid was extracted from $400 \mu$ of the stool samples in a final elution volume of 110 ul by using Nucli SENS Easy MAG automated nucleic acid extractor instrument (Biomeuriex) as per the manufacturer's instructions. In brief, $400 \mu 1$ homogenized stool sample with $1600 \mu$ lysis buffer was add in column tube. $140 \mu$ of magnetic silica was added to the sample with internal control, mixed well by up \& down followed by automated processing. The nucleic acid was eluted in a volume of $110 \mu$ and processed for multiplex PCR

\section{Master Mix preparation}

Preparation of the master mix, primer probe mix was first prepared. For each reaction, PPM was prepared using $0.2 \mu \mathrm{l}$ (4 picomole) of forward primer, $0.2 \mu 1$ (4 picomole) of reverse primer and $0.2 \mu 1$ ( 2 picomole) of probe. Master mix for each reaction was prepared in a total reaction volume of $20 \mu \mathrm{l}$ volume which consisted of $12.5 \mu \mathrm{l}$ of $2 \mathrm{X}$ RT-PCR buffer, $0.5 \mu$ l of 25X RT-PCR enzyme, $1.4 \mu \mathrm{l}$ of nuclease free water, $0.6 \mu \mathrm{l}$ of primer probe mix and $5 \mu$ l of extracted nucleic acid. The thermal cycling profile for PCR was; $50^{\circ} \mathrm{C}$ for 30 


\section{JMSCR Vol||06||Issue||06||Page 846-852||June}

minutes ( 1 cycle), $95^{\circ} \mathrm{C}$ for 10 minutes $(1$ cycle $)$ followed by $90^{\circ} \mathrm{C}$ for 15 seconds and $55^{\circ} \mathrm{C}$ for 30 seconds ( 45 cycles). In each run, a positive control and a negative control was included. The primers and probe sequences for detection of RV in PCR are given as follows.

\begin{tabular}{lccc}
\hline Forward $\left(\mathbf{5}^{\prime}-\mathbf{3}^{\prime}\right)$ & Reverse $\left(\mathbf{5}^{\prime}-\mathbf{3}^{\prime}\right)$ & Probe $\left(\mathbf{5}^{\prime}-\mathbf{3}^{\prime}\right){ }^{\circledR}$ & Reference $^{\circledR}$ \\
\hline ACCATCTWCACRTRACCC & GGTCACATAACGCCCC & \$NED- & Liu et al., \\
TCTATGAG & ATAGC & AGTTAAAAGCTAACACTGTCAAA & 2013 \\
\hline
\end{tabular}

\section{Statistical Analysis}

Statistics like sensitivity, specificity was performed between the two tests performed and one was gold standard (FTD)

\section{Results}

A total of 135 stool samples from hospitalized children of age $\leq 5$ years were tested for Human RV infection by both ELISA and RT-PCR techniques, out of which, $100(74.07 \%)$ were from males and $35(25.93 \%)$ were from females. A total of $20 / 135(14.81 \%)$ samples were found to be positive for RV detected by ELISA technique and among these, 18 (18.00\%) were from males and 2 (5.71\%) were from females. And 33/135 (24.44\%) samples were found to positive for RV detected by RT-PCR technique and among these, 28 $(28.00 \%)$ were from males and $5(14.28 \%)$ were from females.

Table:-1 Sex wise distribution of positive cases of RV infection by detected both techniques

\begin{tabular}{lccccc}
\hline & No. of Patients & \multicolumn{2}{c}{ ELISA } & \multicolumn{2}{c}{ RT-PCR } \\
\cline { 3 - 6 } Male & & Positive & Negative & Positive & Negative \\
Female & $100(70.07 \%)$ & $18(18.00 \%)$ & $82(82.00 \%)$ & $28(28.00 \%)$ & $72(72.00 \%)$ \\
Total & $35(25.93 \%)$ & $2(5.71 \%)$ & $33(94.29 \%)$ & $5(14.28 \%)$ & $30(85.72 \%)$ \\
\hline
\end{tabular}

Figure:-1 Sex wise distribution of sample collected and positivity detected by both techniques

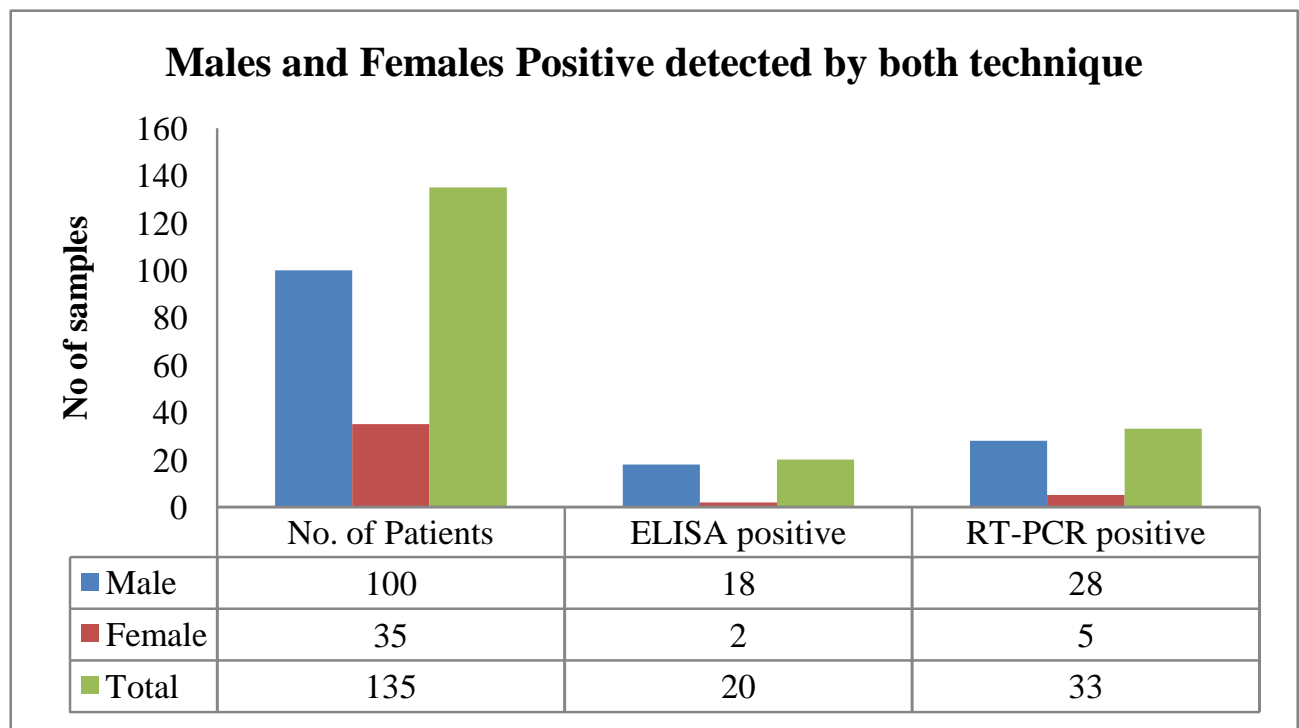

Age wise distribution of RV infected samples detected by both techniques is shown in table 2 . The maximum numbers of samples were collected from children with age group 1-6 months and 7-12 months as compared to 19-24 months age group from which minimum number of samples were collected. Also children less than 2 year age were found to be infected more than in elder age groups.

The positivity of RV in different age grouped children using both techniques is shown in table 2 . Higher positivity was seen with those tested by 


\section{JMSCR Vol||06||Issue||06||Page 846-852||June}

PCR as compared to ELISA technique. The total $14.81 \%$ only while by PCR was $24.44 \%$. positivity of RV by ELISA was found to be

Table: 2 Age wise distribution of RV detected by both techniques

\begin{tabular}{lccccc}
\hline \multirow{2}{*}{$\begin{array}{l}\text { Age groups } \\
\text { (months) }\end{array}$} & $\begin{array}{c}\text { Number of } \\
\text { Samples }\end{array}$ & \multicolumn{2}{c}{ ELISA } & \multicolumn{2}{c}{ RT-PCR } \\
\cline { 3 - 6 } & & Positive & Negative & Positive & Negative \\
$\mathbf{1 - 6}$ & 50 & $6(12.00 \%)$ & $44(88.00 \%)$ & $10(20.00 \%)$ & $40(80.00 \%)$ \\
$\mathbf{7 - 1 2}$ & 49 & $10(20.41 \%)$ & $39(79.59 \%)$ & $15(30.61 \%)$ & $34(69.39 \%)$ \\
$\mathbf{1 3 - 1 8}$ & 14 & $2(14.28 \%)$ & $12(85.72 \%)$ & $4(28.57 \%)$ & $10(71.43 \%)$ \\
$\mathbf{1 9 - 2 4}$ & 9 & $0(0.0 \%)$ & $9(100 \%)$ & $2(22.22 \%)$ & $7(77.78 \%)$ \\
$\mathbf{2 5 - 3 0}$ & 3 & $0(0.0 \%)$ & $3(100 \%)$ & $0(0.0 \%)$ & $3(100 \%)$ \\
$\mathbf{3 1 - 3 6}$ & 2 & $0(0.0 \%)$ & $2(100 \%)$ & $0(0.0 \%)$ & $2(100 \%)$ \\
$\mathbf{3 7 - 4 2}$ & 0 & - & - & - & - \\
$\mathbf{4 3 - 4 8}$ & 4 & $0(0.0 \%)$ & $4(100 \%)$ & $0(0.0 \%)$ & $4(100 \%)$ \\
$\mathbf{4 9 - 5 4}$ & 2 & $1(50.00 \%)$ & $1(50.00 \%)$ & $1(50.00 \%)$ & $1(50.00 \%)$ \\
$\mathbf{5 5 - 6 0}$ & 2 & $1(50.00 \%)$ & $1(50.00 \%)$ & $1(50.00 \%)$ & $1(50.00 \%)$ \\
TOTAL & 135 & $20(14.81 \%)$ & $115(85.19 \%)$ & $33(24.44 \%)$ & $102(75.56 \%)$ \\
\hline & & & & & \\
\hline
\end{tabular}

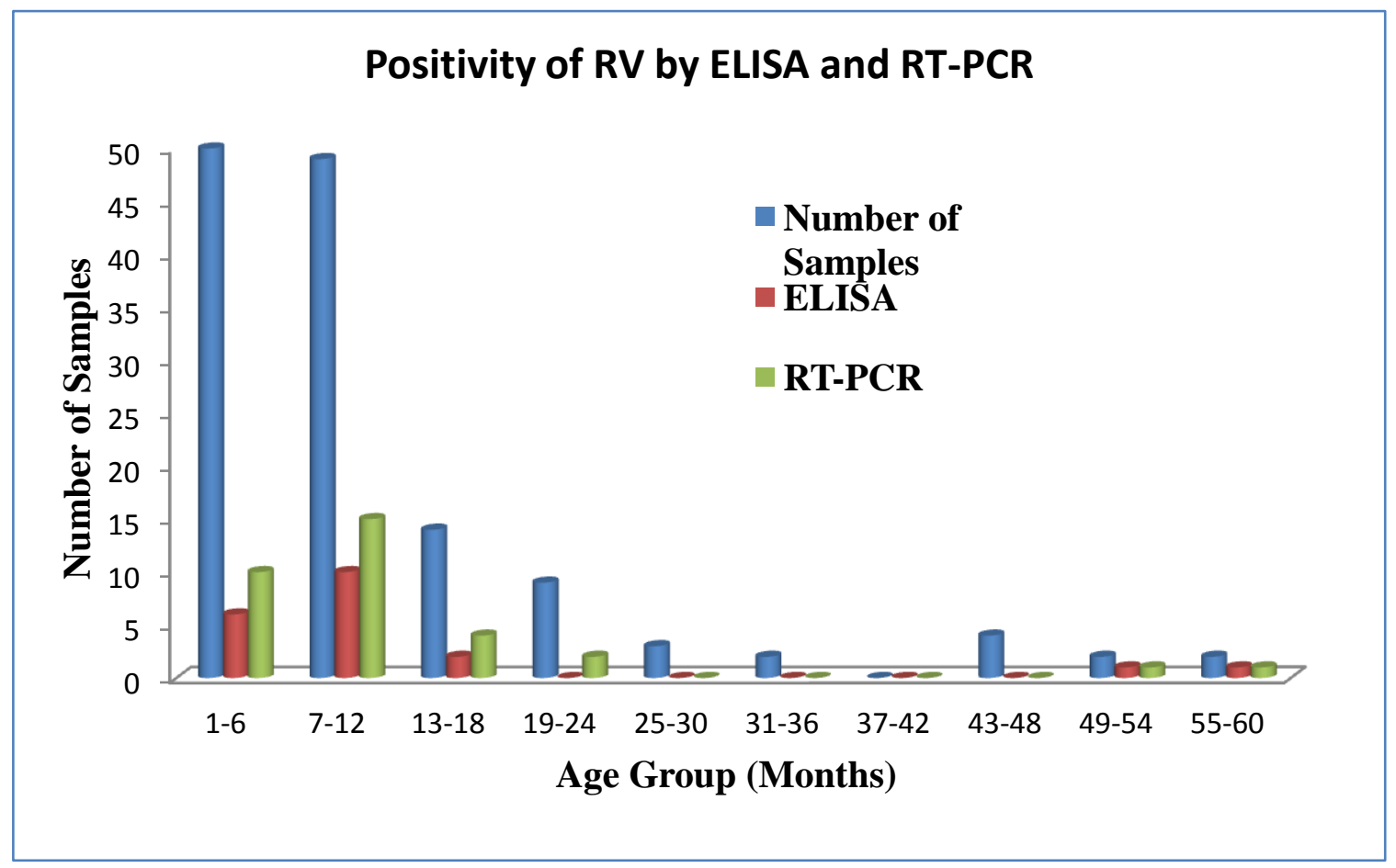

Figure:-2 Age wise distribution of RV detected by both techniques

\section{Comparison of RT-PCR and ELISA with regard to specificity and sensitivity}

We used two different diagnostic techniques in samples for the detection of RV using the same FTD standard. The following $2 \times 2$ tables result:

Table:- 3 Comparison of RT-PCR and ELISA with regard to specificity and sensitivity

\begin{tabular}{lcc}
\hline ELISA & RV(+) & RV(-) \\
\hline Positive & 17 & 2 \\
Negative & 14 & 66 \\
\hline
\end{tabular}

\begin{tabular}{lcc}
\hline PCR & RV(+) & RV(-) \\
\hline Positive & 33 & 0 \\
Negative & 0 & 68 \\
\hline
\end{tabular}

\begin{tabular}{lcc}
\hline Techniques & Sensitivity & Specificity \\
\hline ELISA & $54.83 \%$ & $94.12 \%$ \\
PCR & $100 \%$ & $100 \%$ \\
\hline
\end{tabular}


The sensitivity of ELISA is $\sim 55 \%$ while for PCR $100 \%$ (almost double). Similarly specificity of RT-PCR (100\%) is greater than ELISA (94.12\%). The above tables cleared that RT-PCR techniques is better than ELISA.

\section{Discussion}

Several decades after the rotavirus description many studies have been carried out to compare detection techniques ${ }^{(11,16-21)}$. Currently, several commercial tests are available from less laborious based techniques that enable a quick diagnosis, e.g. antigen detection methods, to more complex tests such as the polymerase chain reaction ${ }^{(22-24)}$

In the present study we collected the samples of children under 5 year age locating around Jaipur (Rajasthan). One year aged children were more affected by RV according to data of our sample collection. When we see sex wise distribution, the positivity of Males was greater than Females. And this pattern is similar for both ELISA and RTPCR techniques. We observed the positivity of $\mathrm{RV}$ by RT-PCR is greater than ELISA in age group from 1-24 months.

Presence of Human Rota virus antigen was detected in 135 stool samples by ELISA. A total of 20/135 (14.8\%) samples were found to be positive for RV infection by ELISA. Positivity of RV by PCR was 33/135 (24.44\%). The data was found to be similar to studies made elsewhere. Studies conducted in Iran, reported that rotavirus was detected in 15.3-26.3\% of children with gastroenteritis and the highest incidence of infection was in children aged 1-12 months (Khalili B, et al., 2004) However, studies from Iran also reported the PCR positivity of Rotavirus between 20.6\%-32\% (Modaress et al., 2010). The positivity of RV by ELISA was significantly lower than by PCR custom assay. The sensitivity and specificity of PCR for detection of RV was $100 \%$, while for ELISA it was found to be $54.83 \%$ and $94.12 \%$ in our study. In Saudi Arabia, rotavirus is an important cause of severe diarrhea among children. The prevalence of rotavirus infection ranged from 10 to $46 \%$ with an average of $30 \%$. Most of the cases were among children less than 2 years of age, and particularly in the first year of life (Al- Bwardy et al., 1988; AlFreihi et al., 1993; Ghazi et al., 2005; Kheyami et al., 2006). The ELISA positivity of Rotavirus from Tunisia was reported as $26.2 \%$ (Trabelsi et al., 2010). Because of the large quantities of rotavirus present in stool samples from children with gastroenteritis, the viral nucleic acid segments can be visualized directly after extraction from virus particles, by electrophoresis on acrylamide gels, and staining with ethidium bromide or silver nitrate. For Group A rotaviruses, most samples that are positive for rotavirus by EIA will be positive for the characteristic pattern of rotavirus RNA segments after electrophoresis and silver staining. In some cases, silver nitrate staining of viral nucleic acid has roughly the same sensitivity as EIA methods. Consequently, the PAGE method has sometimes been used to diagnose Group A rotavirus infections for surveillance studies. However, this method is very labor intensive and time consuming. A variety of sensitive conventional or real-time reverse transcription polymerase chain reaction (RT-PCR) methods have been developed based on primers specific for several different rotavirus genes. These methods have been particularly useful in detecting rotavirus in extra-intestinal tissues, in studies of the duration of viral shedding in stool and the correlation between disease severity and virus load. RT-PCR is also useful for verifying that RNA extracts contain intact rotavirus RNA.

\section{Conclusion}

So we can conclude that RT-PCR technique is better than ELISA for the detection of RV from above discussion.

\section{References}

1. Logan C, John J, O Leary and Niamh O Sullivan. 2006. Rotavirus and Adenovirus as causative agents of acute viral gastroenteritis in children our Lady's Hospital for Sick. $J$ Clin Microbiol Infect Dis. 44: 3189-3195. 
2. Parkin PC, Macarthur, Khambalia A, Goldman RD and Friedman JN. 2009. Clinical and laboratory assessment of dehydration severity in children with acute gastroenteritis. Clin. Pediatr. 49: 235-239.

3. Tate JE, Burton AH, Boschi-Pinto C, Steele D, Duque J and Parashar UD. 2012. Estimate of worldwide rotavirus-associated mortality in children younger than 5 years before the ntroduction of universal rotavirus vaccination programmes: a systematic review and metaanalysis. Lancet Infect Dis. 12(2): 136-141.

4. Weekly Epidemiological Record, vol. 83, no. 47, 21 November 2008.

5. Charles MD, Holman RC, Curns AT, Parashar UD, Glass RI and Breese JS. 2006. Hospitalizations associated with Rotavirus gastroenteritis in the United States 19932002. . Pediat Infect Dis. 25: 489-493.

6. Parashar UD, Glass RI, Jain V and Bhan MK. 2001. Epidemiology of rotavirus in India. Indian J Pediatr. 68: 855-862.

7. Parashar UD, Bresee JS and Glass RI. 2003. The global burden of diarrheal disease in children. Bull World Health Organ. 81: 236236.

8. Ferreira T, Becho MC, Bernardo AR, Chaves TCB, Ribeiro RS and de Lima JS. 2006. Performance of A Latex Agglutination Test in The Diagnosis of Acute Gastroenteritis by Rotavirus. Brazilian J Microbiol. 37(5): 8789.

9. Yasmon A, Harahap ED, Dwipoerwantoro PG and Dewi BE. 2010. Detection of human group $\mathrm{A}$ and $\mathrm{C}$ Rotaviruses in pediatric patients with acute gastroenteritis by real time RT-PCR assay: A preliminary study. Makara Kesehatan. 14(2): 65-69.

10. Beards GM, Campbell AD and Cottrell NR .1984. Enzyme-linked immunosorbent assays based on polyclonal and monoclonal antibodies for rotavirus detection. $J$ Clin Microbiol. 19(2): 248-254.

11. Buesa J, Colomina J, Raga J, Villanueva A and Prat J. 1996. Evaluation of reverse transcription and polymerase chain reaction (RT/PCR) for the detection of rotaviruses: applications of the assay. Res Virol. 147(6): 353-361.

12. Ferreira T, Becho M and Bernardo A. 2006. Performance of a latex agglutination test in the diagnosis of acute gastroenteritis by rotavirus. Braz J Microbiol. 37(4): 587-589.

13. Kasempimolporn S, Louisirirotchanakul S, Sinarachatanant P and Wasi C. 1988. Polyacrylamide gel electrophoresis and silver staining for detection of rotavirus in stools from diarrheic patients in Thailand. J Clin Microbiol. 26(1): 158-160.

14. Gibson, UE, Heid CA and Williams PM. 1996: A novel method for real-time quantitative RT-PCR. Genome Res. 6: 99 3.5-1001.

15. Ramani and Kang. 2008. Indian J Med Res. Author manuscript; available in PMC 2008 page 2, July 17.

16. Bellamy K, Gardner PS, Hambling MH, Rice S and Bradburne AF. 1983. Enzyme-linked immunosorbent assay for the detection of human rotavirus in stools. J Virol Methods. 7(2): 65-72.

17. Berthiaume L, Alain R, McLaughlin B, Payment P and Trepanier P. 1981. Rapid detection of human viruses in faeces by a simple and routine immune electron microscopy technique. J Gen Virol. 55(Pt 1): 223-227.

18. Grauballe PC and Jarzabek Z. 1984. Comparison of indirect double antibody and double antibody sandwich ELISA techniques with latex agglutination test for the diagnosis of human rotavirus infection. Acta Virol. 28(1): 59-63.

19. Middleton PJ, Holdaway MD, Petric M, Szymanski MT and Tam JS. 1977. Solidphase radioimmunoassay for the detection of rotavirus. Infect Immun. 16(2): 439-444.

20. Nakagomi O, Nakagomi A and Suto T. 1982. Detection of human rotavirus by reversed passive hemagglutination (RPHA) using 
antibody against a cultivable human rotavirus as compared with electron microscopy (EM) and enzyme-linked immunosorbent assay (ELISA). Microbiol Immunol. 26(8):747-751.

21. Raboni SM, Nogueira MB, Hakim VM, Torrecilha VT, Lerner H and Tsuchiya LR. 2002. Comparison of latex agglutination with enzyme immunoassay for detection of rotavirus in fecal specimens. Am J Clin Pathol. 117(3): 392-394.

22. Carraro E, Perosa A, Siqueira I, Pasternak J and Martino M. 2008. Four kits evaluation for rotavirus rapid antigen detection in stool samples. Rev Bras Anal Clin. 40(4): 309-311.

23. Masendycz PJ, Palombo EA, Gorrell RJ and Bishop RF. 1997. Comparison of enzyme immunoassay, PCR, and type-specific cDNA probe techniques for identification of group $\mathrm{A}$ rotavirus gene 4 types (P types). J Clin Microbiol. 1997; 35(12): 3104-3108.

24. Momenzadeh A, Modarres S and Faraji A. 2008. Comparision of enzyme immunoassay, immunochromatography, and RNApolyacrylamide gel electrophoresis for diagnosis of rotavirus infection in children with acute gastroenteritis. Iran J Med Sci. 33(3): 173-176.

25. Khalili B. 2004. Epidemiology of rotavirus diarrhoea in Iranian children. J Med Virol. 73: 309-312.

26. Modaress S, Rahbarimanesh AA, Edalat R, Sohrabi A, Modarres S, Gomari H, Motamedirad M, and Sayari AA. 2010. Human Rotavirus Genotypes Detection among Hospitalized Children, A study in Tehran, Iran. Archives of Iranian Medicine. 14: 39-45.

27. Al-Bwardy MA. 1988. Bacterial, parasitic and viral enteropathogens associated with diarrhoea in Saudi children. Annals of Tropical Pediatrics. 8: 26-30.

28. Al-Freihi H, K Twum-Danso, M Sohaibani, H Bella, M el-Mouzan and K Sama. 1993.
The microbiology of acute diarrhoeal disease in the eastern province of Saudi Arabia. East Afr Med J. 70: 267-269.

29. Ghazi HO, Khan MA, Telmesani AM, Idress B and Mahomed MF. 2005. Rotavirus infection in infants and young children in Makkah, Saudi Arabia. J Pak Med Assoc. 55: 231-234.

30. Kheyami AM, Cunliffe NA and Hart CA. 2006. Rotavirus infection in Saudi Arabia. Ann of Saudi Med. 26: 184-191.

31. Trabelsi A, Peenze I, Pager C, Jeddi M and Steele D. 2000. Distribution of rotavirus VP7 serotypes and VP4 genotypes circulating in Sousse, Tunisia, from 1995 to 1999 : emergence of natural human reassortants. $J$ Clin Microbiol. 38: 3415-3419. 